\title{
Numerical analysis of settlement of a high-rise building using two constitutive soil models
}

\author{
Leszek Chomacki ${ }^{1, *}$ \\ ${ }^{1}$ Building Research Institute, Building Structures, Geotechnics and Concrete Department, ul. Filtrowa 1 00-611 Warszawa, Poland
}

\begin{abstract}
One of the basic roles of foundations is to safely transfer loads from the structure to the subsoil in a controlled manner. Often a key parameter in deciding whether the foundation was designed correctly is the value of settlement of the building and the ground around it. This paper attempts to numerically reproduce the measured settlement of a high-rise building using geotechnical parameters already available. For this purpose, numerical calculations were carried out using two constitutive soil models: the elastic-perfectly plastic model with Mohr-Coulomb plastic criteria (MC) model and the Hardening Soil (HS) model. The resulting settlement values were compared with surveying measurements taken during and after the building's construction. In the summary the results obtained with the use of different constitutive models, the calculation process and the adopted soil parameters are analysed and discussed.
\end{abstract}

\section{Introduction}

Due to rising land prices, Poland is currently experiencing a tendency to build increasingly high buildings. In the design of high-rise buildings the building's foundations are of key importance. One of the basic roles of foundations is to safely transfer loads from the structure to the subsoil in a controlled manner. Often a key parameter in deciding whether the foundation was designed correctly is the value of settlement of the building and the ground around it. Smaller settlement translates to a safer structure; however it is directly tied to higher costs of the design and execution of foundations.

This paper attempts to numerically reproduce the settlement of a selected high-rise building and the results are compared with surveying measurements taken during and after its construction.

\section{Description of the structure and soil conditions}

\subsection{Description of the superstructure}

Maximum dimensions of the building in plan are ca. 100 $\mathrm{x} 80 \mathrm{~m}$. The lowest storey covers most of the land plot and is partially located underground. The main elements of this complex are two towers: the higher (labelled " $\mathrm{A}$ " in fig. 1) consists of 36 storeys and is $125.4 \mathrm{~m}$ high, while the lower one (labelled "B" in fig. 1) consists of 28 storeys and is $93.8 \mathrm{~m}$ high.

The building's structure is made of in-situ reinforced concrete [1]. The load bearing system is a slab-column frame, and the stiffening role is performed by the walls of the towers' cores.

\subsection{Description of the foundation}

The foundation is a slab of varying thickness, adjusted depending on the loads. For the most part, the Ycoordinate of the top of the foundation slab under the structure is $-3.25 \mathrm{~m}$ (1.95 $\mathrm{m}$ m.a.s.l.).

Slurry walls were built under the towers and at the waterfront, with a width of $0.8 \mathrm{~m}$ or $1.0 \mathrm{~m}$. The walls underneath the towers (fig. 1) transfer the major loads to greater depths, and therefore minimise the settlement and differences in settlement [2]. The wall at the waterfront (fig 2) is supposed to reduce potential horizontal displacement of the soil, which could reach the waterfront caissons and damage (displace) them.

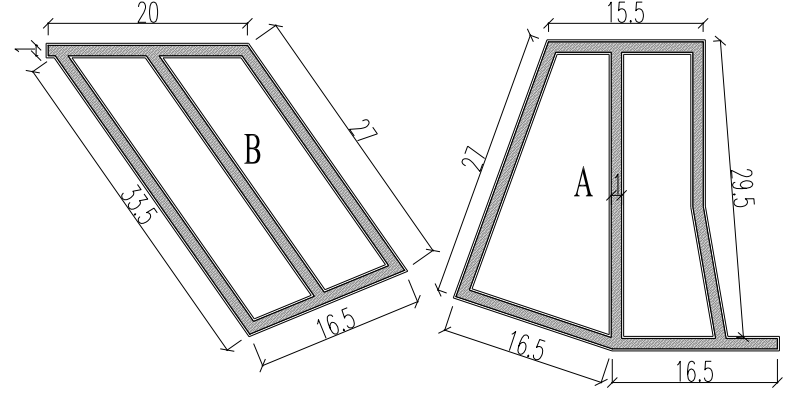

Fig. 1. Placement and dimensions of the slurry walls under the towers $[\mathrm{m}]$.

Under the main structural axes in the tower areas $1 \mathrm{~m}$ wide slurry walls were built. They are supported and anchored below the top of geologic layer III, at $-17.70 \mathrm{~m}$. The total height of the walls is $11.45 \mathrm{~m}$ under the higher tower and 12.05 under the lower one.

The reinforced concrete bottom slab is an element with thickness varying between 0.6 and $2.4 \mathrm{~m}$ [1]. In plan,

\footnotetext{
$\overline{{ }^{*} \text { Corresponding author: } 1 . \text { chomacki@itb.pl }}$
} 
the shape of the slab is close to a $80 \times 100 \mathrm{~m}$ rectangle. The top of the slab is on main five levels, between $-2.85 \mathrm{~m}$ to $-4.45 \mathrm{~m}$. Location of the slabs, their thickness and coordinates of their top plane are marked (in red) in fig. 2.

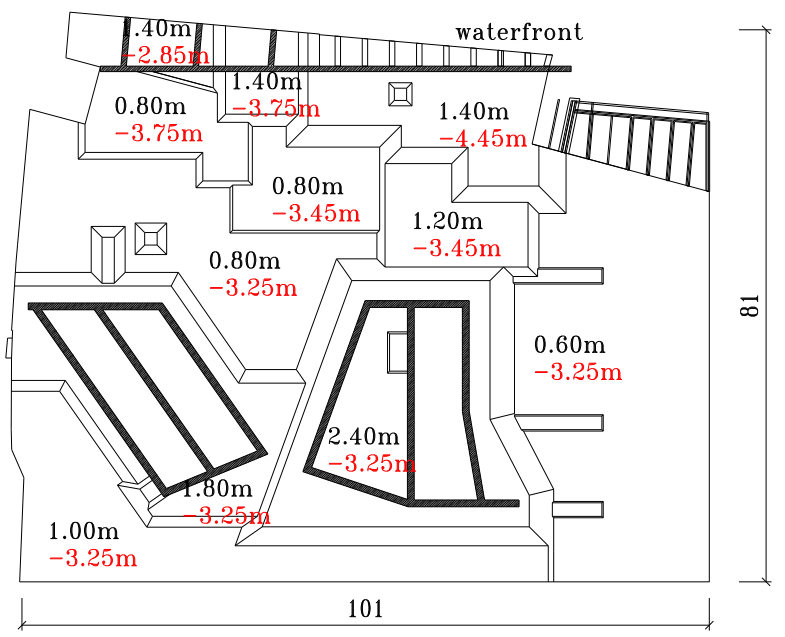

Fig. 2. Foundation slabs, their thickness and coordinates of top plane (in red) [m].

\subsection{Soil conditions}

The site on which the building is erected used to be part of the Baltic sea basin. In the 1930s, a decision was made to build a new waterfront, and in order to obtain a larger dry area, the waterfront's caissons were submerged in the sea [3]. The space between the caissons and the land was filed with the materials obtained from dredging the waterway. It was mainly sand, and its degree of compaction after dumping can be described as loose. This layers needed to be compacted in order to limit the settlement of the high-rise building.

Under a layer of surface embankments created during extension of the waterfront, there are Quaternary formations $[4,5]$. The main components to a depth of 8$10 \mathrm{~m}$ are Holocene river sands and sand-gravel mixes. They are characterised by varying grain size and they are loose (IIa) or medium dense (IIb). At this depth there were also two thin (0.1-0.3 m) non-continuous interbedded layers of sandy organic soil (I). In the lower sections they are mainly medium and fine dense sands (sometimes with some humus or shells) (IIc).

Below that there are Pleistocene formations: fluvioglacial sands of different grain size (mostly medium or coarse), sand-gravel mix with boulders and gravel (IIIa and IIIb). Their degree of compaction is described as dense or medium dense.

At a depth of $35 \mathrm{~m}$ and more we can find tertiary marine clay (IV a and IV b). The thickness of these layers is 2 to $5 \mathrm{~m}$ and they are discontinuous. The clay has interbedded layers of fine and medium sand with high density (IIc). Moreover small deposits of coal can be found in this geologic layer. This composition probably continues to a depth of $100 \mathrm{~m}$, i.e. until the top of the Cretaceous limestone.
The soil composition under the development was investigated to a depth of c. $60 \mathrm{~m}$, and a sample crosssection is presented in fig. 3 .

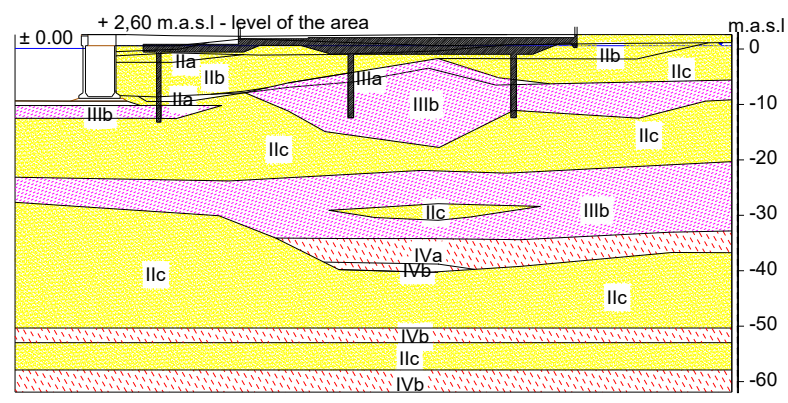

Fig. 3. Example cross-section through the development ground [6].

The necessity to strengthen the current soil affected mostly layers IIa and IIb which were loose and medium dense, with a small thickness. Layer IIa was mostly removed during excavation work for the foundations, while layer IIb was compacted mechanically using vibroflotation. The vibroflotation was performed after the slurry walls hardened in order to best compact the space between the walls and under the towers. A total of 1112 vibroflotation points were used of a total length of 6853 $\mathrm{m}$, distributed in a grid of $2 \times 2 \mathrm{~m}$ or $3 \times 3 \mathrm{~m}$.

Using boreholes made at different times of the year during several years it can be determined that there is a water table present (locally under pressure from lenses of organic soils) at $-4.5 \mathrm{~m}$ to $-5.0 \mathrm{~m}$.

\subsection{Geotechnical conditions}

Characteristic values for each layer were based on macroscopic examinations, laboratory tests, pressuremeter and dilatometer tests as well as various probings. The most significant geotechnical parameters of the subsoil under the building are collected in table 1 .

\section{Calculations}

\subsection{General and geometric data}

The program chosen to perform the calculations was Plaxis 3D Foundation. It is based on solving a system of differential equations using the finite element method (FEM).

To model the problem, three-dimensional, 15-node finite elements were used, containing 6 Gauss interpolation points [7]. They were built by introducing a space perpendicular to a two-dimensional mesh and placing additional nodes on the edges. Higher density of the mesh increases precision of the calculations but also extends the time to obtain result. The program adjusts the three-dimensional mesh (in the third dimension) based on the layers submitted and working planes. The numerical model comprised over 31000 elements (fig. 4) and the total calculation time was 7 to 10 hours. 
Table 1. Geotechnical parameters [8].

\begin{tabular}{|l|l|c|c|c|c|c|c|c|c|c|c|}
\hline Name & \multicolumn{1}{|c|}{$\begin{array}{c}\text { Soil } \\
\text { type }\end{array}$} & $\begin{array}{c}\mathrm{I}_{\mathrm{D}} / \mathrm{I}_{\mathrm{L}} \\
-\end{array}$ & $\begin{array}{c}\gamma \\
{\left[\mathrm{kN} / \mathrm{m}^{3}\right]}\end{array}$ & $\begin{array}{c}\mathrm{c}^{\prime} \\
{[\mathrm{kPa}]}\end{array}$ & $\begin{array}{c}\phi^{\prime} \\
{\left[{ }^{\circ}\right]}\end{array}$ & $\begin{array}{c}\mathrm{M}_{\mathrm{o}} \\
{[\mathrm{MPa}]}\end{array}$ & $\begin{array}{c}\mathrm{M} \\
{[\mathrm{MPa}]}\end{array}$ & $\begin{array}{c}\mathrm{E}_{\mathrm{o}} \\
{[\mathrm{MPa}]}\end{array}$ & $\begin{array}{c}\mathrm{E} \\
{[\mathrm{MPa}]}\end{array}$ & $\begin{array}{c}v_{\mathrm{o}} \\
{[-]}\end{array}$ & $\begin{array}{c}\gamma_{\mathrm{m}} \\
{[-]}\end{array}$ \\
\hline $\mathrm{I}$ & Sandy organic soil & 0.40 & 17.1 & 8.0 & 8.0 & 1.2 & 5 & 0.8 & 4.5 & 0.33 & $1 \pm 0.2$ \\
\hline $\mathrm{IIa}$ & $\begin{array}{l}\text { Fine sand, medium } \\
\text { sand, coarse sand }\end{array}$ & 0.25 & 18.5 & 0.0 & 29.0 & 40 & 80 & 33 & 72 & 0.25 & $1 \pm 0.1$ \\
\hline $\mathrm{IIb}$ & $\begin{array}{l}\text { Fine sand, medium } \\
\text { sand, coarse sand }\end{array}$ & 0.50 & 19.0 & 0.0 & 30.5 & 63 & 222 & 50.4 & 200 & 0.27 & $1 \pm 0.1$ \\
\hline $\mathrm{IIc}$ & $\begin{array}{l}\text { Fine sand, medium } \\
\text { sand, coarse sand }\end{array}$ & 0.70 & 20.0 & 0.8 & 31.5 & 86 & 300 & 68.8 & 270 & 0.27 & $1 \pm 0.1$ \\
\hline $\mathrm{IIIa}$ & Sand/gravel mix & 0.70 & 20.5 & 0.0 & 34.0 & 150 & 333 & 135 & 300 & 0.20 & $1 \pm 0.1$ \\
\hline $\mathrm{IIIb}$ & Sand/gravel mix & 0.70 & 21.0 & 0.0 & 35.0 & 192.5 & 389 & 172 & 350 & 0.20 & $1 \pm 0.1$ \\
\hline IVa & Clay, coal & 0.10 & 20.0 & 50.0 & 31.0 & 70 & 267 & 58.3 & 240 & 0.25 & $1 \pm 0.2$ \\
\hline IVb & Clay & 0.00 & 20.0 & 50.0 & 33.0 & 110 & 252 & 90 & 280 & 0.25 & $1 \pm 0.2$ \\
\hline $\begin{array}{l}\text { Engineered } \\
\text { layer }\end{array}$ & $\begin{array}{l}\text { Fine sand, medium } \\
\text { sand, coarse sand }\end{array}$ & 0.70 & 19.0 & 0.0 & 33.0 & 80 & 160 & 59.4 & 144 & 0.30 & $1 \pm 0.1$ \\
\hline
\end{tabular}

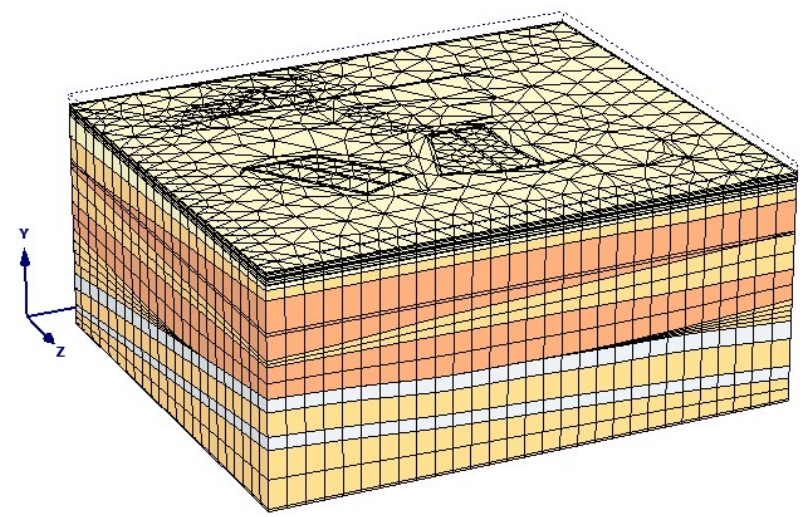

Fig. 4. Calculation model in three-dimensional state of strain.

The entire defined three-dimensional calculation model consists of 3D shapes. Considering the aim of the calculations, which is to evaluate settlement, the adopted solution has been considered correcly.

Unfortunately, it does not allow to fully interpret the behaviour of the foundation under the analysed building. View of the foundation structure with geometry is shown in fig. 5 and 6.

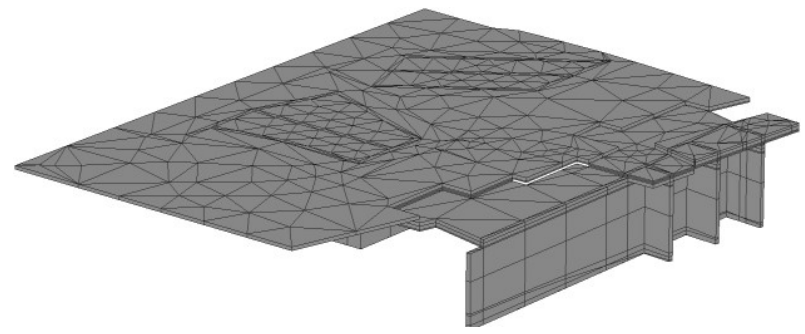

Fig. 5. Top-down view of the foundation from the waterfront side.

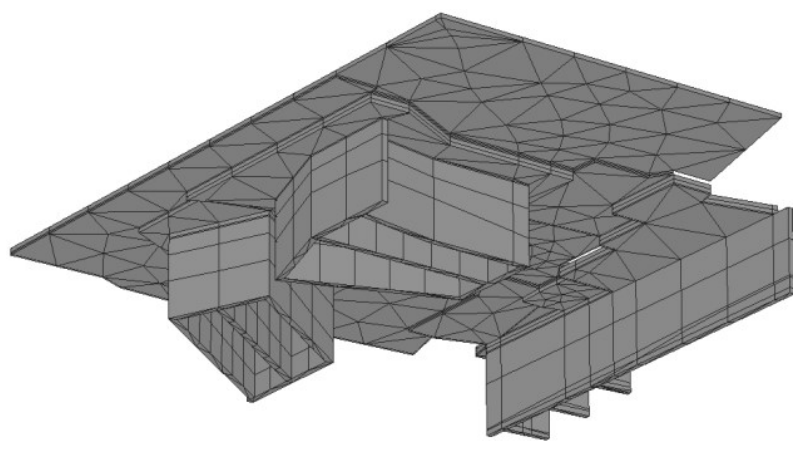

Fig. 6. Bottom-up view of the foundation structure from the land side.

The adopted calculation model was three-dimensional with dimensions in plan 140x120 m and a height of $60 \mathrm{~m}$. With the foundation slab dimensions equal to ca. $100 \times 80$ $\mathrm{m}$, there were $20 \mathrm{~m}$ of free space on each side.

The soil layer data were introduced into the model using five points with coordinates corresponding roughly to the test boreholes. Due to variability of the soil conditions between boreholes, they had to be averaged. The calculations used 10 soil layers. The surface layers IIa and IIb, after the vibroflotation was completed with satisfactory results, could be assumed to have parameters of layer IIc, while layer IIIa - of IIIb. Layers IVa and IVb, due to similar parameters, were assumed to have the same properties determined for IVb for the sake of simplicity. Down to $-40 \mathrm{~m}$ layers IIc and IIIb appear alternately. Below that, to the maximum tested depth, ie. to $-60 \mathrm{~m}$ layers belonging to group IV and IIc appear alternately. The depth of $60 \mathrm{~m}$ (maximum tested depth) was deemed sufficient to properly evaluate settlements. The water table was assumed to be constant at $-4.8 \mathrm{~m}$.

Ultimately two calculation models were defined, differing in the constitutive model of soil medium representation (MC and HS models) and initial calculation phase (phase 0). 


\subsection{Material data}

For the purposes of the calculations 4 materials were defined: concrete, IIc, IIIb, IVb. For each of the 4 materials, representative parameters were adopted based on source data. The data collected in table 2 refer to basic parameters of the elastic model, additional parameters from the MC model and parameters required in the HS model. The description of these parameters can be found in [7].

Table 2. List of parameters used in the calculations [9].

\begin{tabular}{|c|c|c|c|c|}
\hline $\begin{array}{c}\text { Param. } \backslash \mathrm{Ma} \\
\mathrm{t} .\end{array}$ & Concrete & IIc & IIIb & $\mathrm{IVb}$ \\
\hline $\begin{array}{c}\gamma_{\text {unsat }} \\
{[\mathrm{kN} / \mathrm{m} 3]}\end{array}$ & 25.0 & 19.6 & 20.6 & 19.6 \\
\hline $\begin{array}{c}\gamma_{\text {sat }} \\
{[\mathrm{kN} / \mathrm{m} 3]}\end{array}$ & 25.0 & 20.4 & 21.3 & 19.9 \\
\hline $\begin{array}{c}E_{r e f} \\
{[\mathrm{kPa}]}\end{array}$ & $\begin{array}{c}3.00 \mathrm{E}+0 \\
7\end{array}$ & $\begin{array}{c}6.88 \mathrm{E}+0 \\
4\end{array}$ & $\begin{array}{c}1.77 \mathrm{E}+0 \\
5\end{array}$ & $\begin{array}{c}9.16 \mathrm{E}+0 \\
4\end{array}$ \\
\hline$v_{[-]}$ & 0.17 & 0.27 & 0.20 & 0.25 \\
\hline \multicolumn{5}{|c|}{ Additional parameters needed for the MC model } \\
\hline$c_{r e f} \quad[\mathrm{kPa}]$ & - & 1 & 1 & 50 \\
\hline$\varphi_{\left[{ }^{\circ}\right]}$ & - & 31.5 & 35.0 & 33.0 \\
\hline \multicolumn{5}{|c|}{ Additional parameters needed in the HS model } \\
\hline $\begin{array}{c}E_{50}^{r e f} \\
{[\mathrm{kPa}]}\end{array}$ & - & $\begin{array}{c}6.20 \mathrm{E}+0 \\
4\end{array}$ & $\begin{array}{c}1.26 \mathrm{E}+0 \\
5\end{array}$ & $\begin{array}{c}8.25 \mathrm{E}+0 \\
4\end{array}$ \\
\hline $\begin{array}{c}E_{\text {oed }}^{r e f} \\
{[\mathrm{kPa}]}\end{array}$ & - & $\begin{array}{c}8.60 \mathrm{E}+0 \\
4\end{array}$ & $\begin{array}{c}1.92 \mathrm{E}+0 \\
5\end{array}$ & $\begin{array}{c}1.10 \mathrm{E}+0 \\
5\end{array}$ \\
\hline $\begin{array}{l}E_{u r}^{r e f} \\
{[\mathrm{kPa}]}\end{array}$ & - & $\begin{array}{c}1.86 \mathrm{E}+0 \\
5\end{array}$ & $\begin{array}{c}3.79 \mathrm{E}+0 \\
5\end{array}$ & $\begin{array}{c}2.37 \mathrm{E}+0 \\
5\end{array}$ \\
\hline$v_{u r}[-]$ & - & 0.20 & 0.20 & 0.15 \\
\hline$p^{r e f}[\mathrm{kPa}]$ & - & 100 & 100 & 100 \\
\hline$K_{0}^{N C}$ & - & 0.48 & 0.50 & 0.50 \\
\hline
\end{tabular}

Table 3 presents Overconsolidation Ratio (OCR) values and the coefficient of earth pressure at rest $\mathrm{K}_{0}$ for 10 layers in the HS model. In the MC model OCR is not defined and $\mathrm{K}_{0}$ is constant for a given material.

Table 3. Values of OCR and $\mathrm{K}_{0}$ parameters in the HS model [9].

\begin{tabular}{|c|c|c|c|c|c|}
\hline Layer & Name & Model & OCR & $\mathrm{K}_{0, \mathrm{x}}$ & $\mathrm{K}_{0, \mathrm{z}}$ \\
\hline 1 & IIc & MC & - & 0,478 & 0,478 \\
\hline 2 & IIc & HS & 1.0 & 0,478 & 0,478 \\
\hline 3 & IIIb & HS & 1.2 & 0,550 & 0,550 \\
\hline 4 & IIc & HS & 1.2 & 0,524 & 0,524 \\
\hline 5 & IIIb & HS & 1.3 & 0,575 & 0,575 \\
\hline 6 & IIc & HS & 1.3 & 0,546 & 0,546 \\
\hline 7 & IVb & HS & 1.5 & 0,662 & 0,662 \\
\hline 8 & IIc & HS & 1.5 & 0,592 & 0,592 \\
\hline 9 & IVb & HS & 1.5 & 0,662 & 0,662 \\
\hline 10 & IIc & HS & 1.5 & 0,592 & 0,592 \\
\hline
\end{tabular}

\subsection{Calculation phases}

For both calculation models (MC and HS) calculation phases are identical with the exception of the initial phase. Stages of the calculations are presented below.

Phase 0 - initial one. The difference lies in the method of calculating geostatic stress in the soil. For the MC model it involved gravity loading, which is a common practice, while for the HS model - the $\mathrm{K}_{0}$ procedure.

The $\mathrm{K}_{0}$ procedure uses the Overconsolidation Ratio, which results in increasing the $\mathrm{K}_{0}$ coefficient. This is of significance for evaluation of horizontal stress in the overconsolidated soil layers.

After the calculations, settlements were reset.

Phase 1 -slurry walls. The soil material was replaced with concrete material. The slurry walls begin and end at coordinates consistent with the design and as-built design. After the calculations, settlements were reset.

Phase 2 - foundation slabs The soil material was replaced with concrete material. There are 4 different Ycoordinates of the top plane of the slab. After the calculations, settlements were reset.

Phases 3-9 - gradual application of loads distributed in time, consistent with the construction times of the building.

In order to obtain reliable curves of settlement over time, the load needed to be applied gradually at specific intervals of time. Concreting logs served as basis for estimating loads and the time at which they appeared. The final loads applied to the foundation slabs are presented in fig. 7. The loads were applied at the level of the foundation slab top plane.

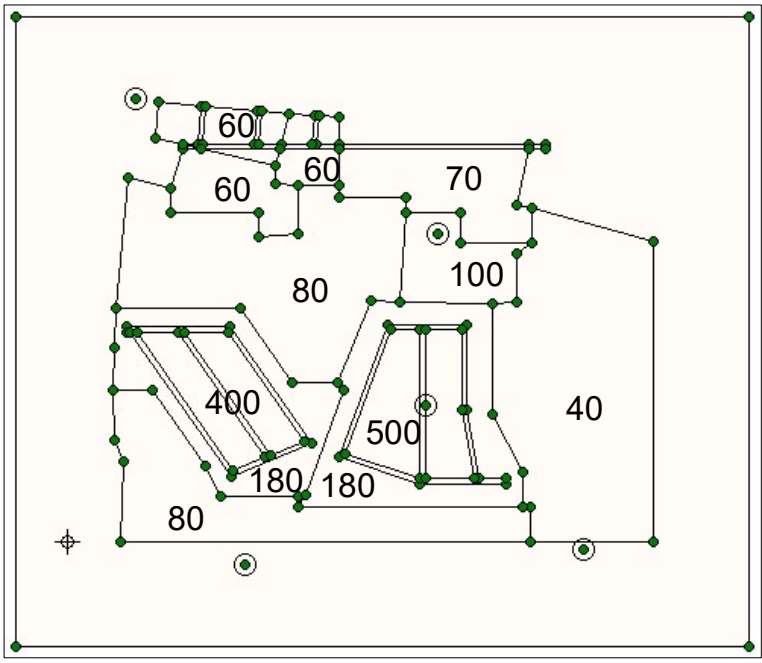

Fig. 7. Drawing of loads applied to the model [kPa]

\section{Discussion of results}

\subsection{Contour map of settlement values}

The results obtained in the calculations for the two calculation models differ considerably (fig. 8 and 9). They 
are also different from the real settlements measured (fig. $10)$.

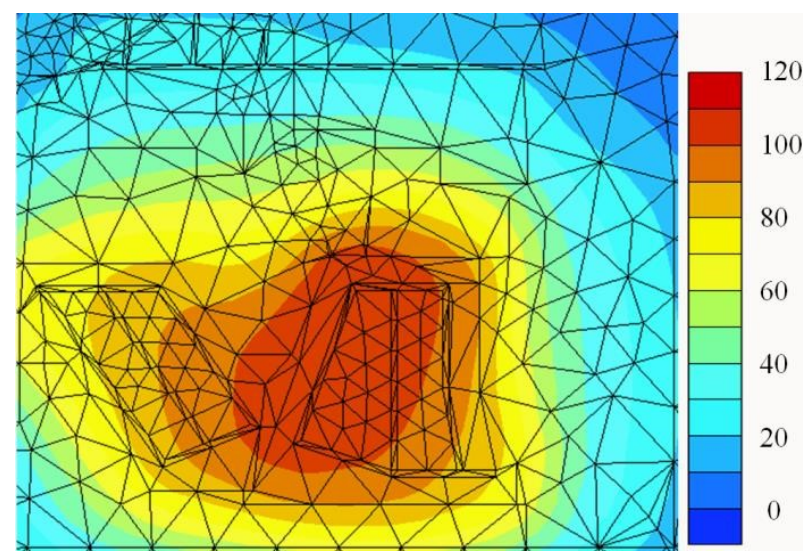

Fig. 8. Results of settlement calculations for the MC model for the final load [mm].

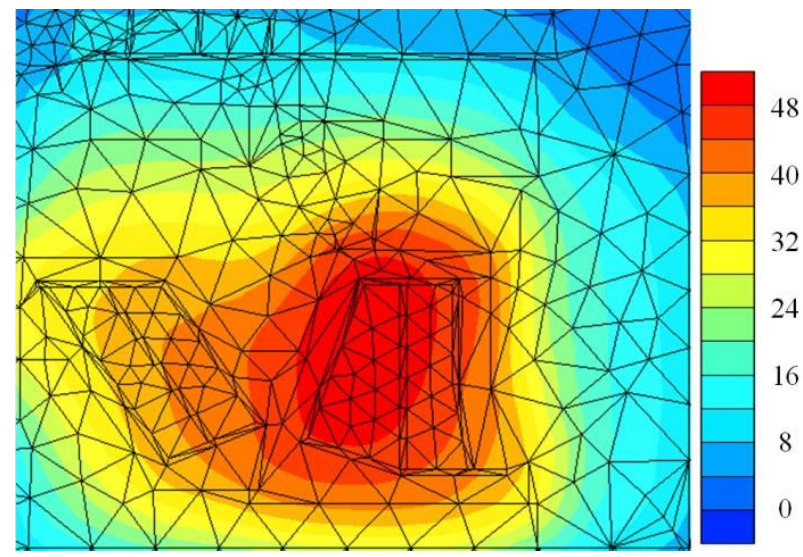

Fig. 9. Results of settlement calculations for the HS model and final load $[\mathrm{mm}]$.

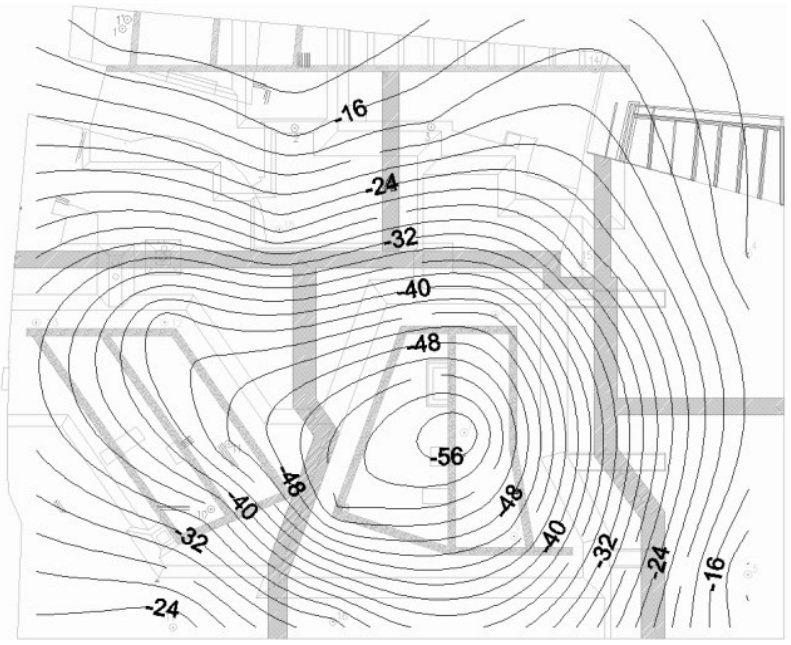

Fig. 10. Contour line of the settlement for the final load [mm].

For both models, the greatest settlement values were obtained for the higher tower - in the MC model that value was equal to $110 \mathrm{~mm}$, while for the HS model it was 52 $\mathrm{mm}$. The maximum settlement measured was equal to 56 $\mathrm{mm}$.
The above allows to conclude that the model which produced results closer to reality is the Hardening Soil (HS) model.

The obtained contour maps indicate that it would be highly recommended to repeat calculations for a model with larger plan dimensions than the adopted $140 \times 80 \mathrm{~m}$, as settlement values on its edges are higher than zero.

\subsection{Settlement graphs}

The graphs were created based on measurements of real settlement at test points taken during and after construction. It can be assumed that the settlements reached values close to their target values. This can be read from the settlement curve which flattens into a line at the end. The settlement curve for the higher tower is presented in fig. 11, and for the lower tower in fig. 12.

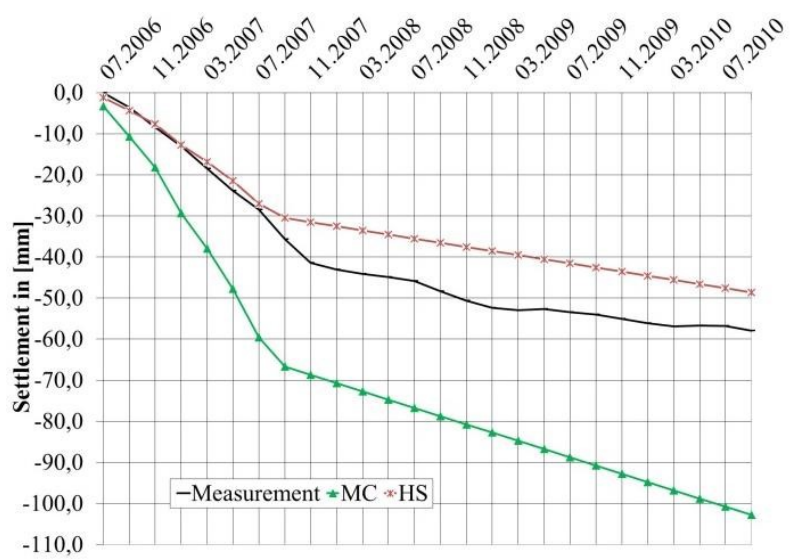

Fig. 11. Graphs of settlement over time at the centre of higher tower.

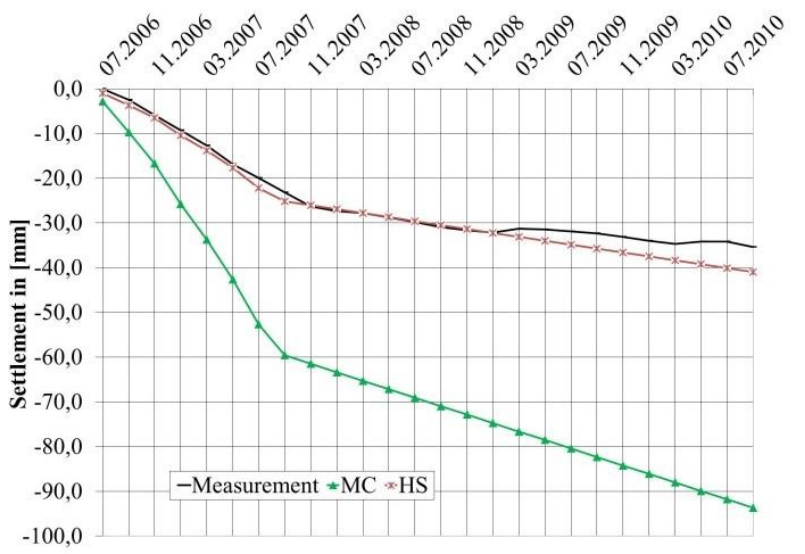

Fig. 12. Graphs of settlement over time at the centre of lower tower.

\subsection{Evaluation of the MC model}

The results obtained from calculations using the MohrCoulomb material model show that settlement values were overestimated about $100 \%$ in comparison with the measured values. This model's performance is considerably different from the HS model and for overconsolidated soils it could not have yielded results close to the real behaviour. 
Distribution of $\mathrm{MC}$ criterion plasticity points is presented in fig. 13.

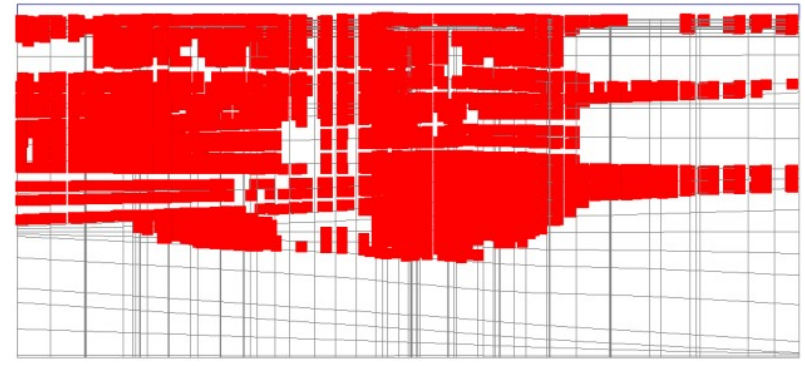

Fig. 13. Distribution of MC criterion plasticity points for the final stage.

As we can see, the soil reached plasticity in many points, and due to poor definition of plasticity in this model, the settlement results were overestimated. It is characteristic that plasticity points can occur at a depth of up to $40 \mathrm{~m}$, which means layers situated below behave in the elastic range.

\subsection{Evaluation of the HS model}

Due to the history of glacial load on the territory of Kashubian Lake District a certain degree of soil overconsolidation is to be expected. This condition should be accounted in calculations, which was done in the Hardening Soil (HS) model.

The resulting final settlement values (fig. 9) are typically slightly underestimated compared to real measured settlement (fig. 10). Fig. 14 shows some strengthening of the soil - through the stress path reaching the cap surface (cap points in blue), or through isotropic compression (hardening points in green). In the surface zone of this model, where the MC material model was adopted for the first layer, plasticity was found in many points, similarly to the MC model.

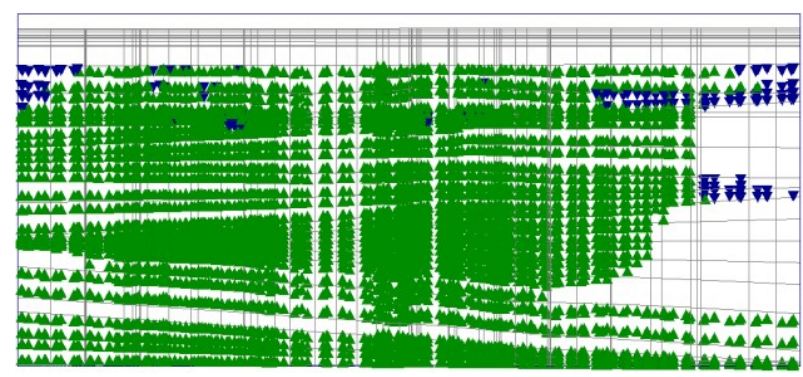

Fig. 14. Distribution of cap points (blue) and hardening points (green) for the final stage in the HS model.

As can be seen, in the HS model, deeper parts of the modelled space were strengthened, thanks to which the settlement values were lower than for the MC model.

In the initial calculations, the OCR parameter was adopted in the range of 1.0-2.0, in accordance with [3]. However, the settlement values resulting from such OCR were considerably lower than the measured ones. Considering the above, and the potential to misjudge the OCR parameter, it was decided to correct these values (table 3).

\section{Conclusions}

The calculations performed show that the Hardening Soil model is the better choice for analysing building foundations on overconsolidated soils.

It is highly recommended to carry out comprehensive field and laboratory tests of soils before designing this type of complex developments, and to use the results of these tests in design. Unfortunately situations in which designers avoid detailed investigation of the construction site still occur. The effect is often overestimating structure dimensions, due to adopting "safe" design parameters. These situations could be avoided by increasing geotechnical examination budget. Savings due to decreasing the structure mass would cover the soil test costs.

Special thanks to Marcin Cudny, PhD Eng for his invaluable help in obtaining data for the calculations and the modelling.

\section{References}

1. A. Matusiak, J. Perzyński, Projekt wykonawczy, tom III: konstrukcja. Biuro Projektów Architektonicznych i Budowlanych (2005)

2. R.P. Cunha, H.G. Poulos, J.C. Small, Journal of geotechnical and geoenvironmental engineering 127, 8 (2001)

3. E. Dembicki, A. Bolt, G. Horodecki, M. Cudny, Inżynieria Morska i Geotechnika 2, 177-185 (2010)

4. J. Kuciaba, W. Woliński, Dokumentacja geologiczno-inżynierska dla projektu budynków apartamentowo - mieszkalnych w Gdyni przy nabrzeżu prezydenta. Fundament (2003)

5. M. Tarnawski, C. Kołodziej, Drugi dodatek do dokumentacji geologiczno-inżynierskiej podłoża projektowanego budynku mieszkalno - usługowego przy ul. Hryniewickiego i Nabrzeżu Prezydenta w Gdyni, Geoprojekt Szczecin (2005)

6. E. Dembicki, A. Bolt, M. Cudny, G. Horodecki, Ekspertyza geotechniczna dotycząca parametrów geotechnicznych badanych gruntów po zakończeniu wibroflotacji, Geosyntex (2005)

7. Material models manual, Plaxis 3D Foundation (2010)

8. E. Dembicki, A. Bolt, G. Horodecki, M. Cudny, Ekspertyza geotechniczna dotycząca parametrów geotechnicznych podłoża gruntowego pod budowę wysokościowego budynku mieszkalno - usługowego w Gdyni przy ul. Hryniewickiego, Geosyntex (2005)

9. L. Chomacki, Master thesis (2011) DOI 10.13140/RG.2.2.22917.76002 